\title{
Carbohydrate fractions of legumes: uses in human nutrition and potential for health
}

\author{
F. Guillon* and M. M.-J. Champ \\ URPOI \& UFDNH, National Institute for Agronomic Research (INRA), Rue de la Géraudière, BP 71627, \\ 44316 Nantes Cedex 03, France
}

\begin{abstract}
Starch and fibre can be extracted, using wet or dry processes, from a variety of grain legumes and used as ingredients for food. $\alpha$-Galactosides can be isolated during wet processes from the soluble extract. Starch isolates or concentrates are mostly produced from peas, whereas dietary fibre fractions from peas and soyabean are commercially available. The physico-chemical characteristics of fibre fractions very much depend on their origin, outer fibres being very cellulosic whereas inner fibres contain a majority of pectic substances. Inner fibres are often used as texturing agents whereas outer fibres find their main uses in bakery and extruded products, where they can be introduced to increase the fibre content of the food. Most investigations on impacts on health have been performed on soyabean fibres. When positive observations were made on lipaemia, glucose tolerance or faecal excretion, they were unfortunately often obtained after non-realistic daily doses of fibres. Legume starches contain a higher amount of amylose than most cereal or tuber starches. This confers these starches a lower bioavailability than that of most starches, when raw or retrograded. Their low glycaemic index can be considered as beneficial for health and especially for the prevention of diseases related to insulin resistance. When partly retrograded, these starches can provide significant amount of butyrate to the colonic epithelium and may help in colon cancer prevention. $\alpha$-Galactosides are usually considered as responsible for flatus but their apparent prebiotic effects may be an opportunity to valorize these oligosaccharides.
\end{abstract}

Legumes: Dietary fibre: Starch: $\alpha$-Galactosides: Human nutrition: Fractionation

\section{Introduction}

Grain legumes are considered to be good for health due to their mutual compatibility with cereals and for their properties in disease prevention, including cardiovascular diseases, type 2 diabetes, obesity and, possibly, colon cancer. The nutritional potential of the seeds from this group of plants is based on their high level of protein and, depending on species, a high proportion of either starch or oil (Table 1). Along with macronutrients, leguminous seeds contain appreciable amounts of some vitamins and minerals as well as dietary fibre. The most common legumes for human consumption are bean, lentil, pea, chickpea and faba bean. Most grain legumes are consumed after simple processing, as vegetables, salads, soups, mashed and cooked seeds.

However, grain legume seeds can be fractionated to obtain protein and starch concentrates and isolates, and as a by-product of the process, dietary fibre. Starch, protein and dietary fibre are indeed the main fractions of most European grain legumes, the main exceptions being lupin and soya, which are both rich in fat (Table 1).

Fractions isolated from grain legumes can be used in the food-processing industry as simple ingredients, technofunctional ingredients or additives. Apart from these technological interests, we wonder whether such products could have real nutritional properties for humans.

Dietary fibre content varies according to the species, the variety and processing of legume seeds. In most grain legumes consumed as pulses by humans, the content ranges from 8 to $27.5 \%$, with soluble fibre in the range $3.3-13.8 \%$. Dietary fibre, or cell wall material, content in the cotyledon of legume seed is generally low compared to that of the testa. Indeed, the cell walls accounted for about $90 \%$ of the testa dry weight.

Brillouet \& Carré (1983) reported values of dietary fibre contents for pea, broad pea and soyabean cotyledons in the range $6 \cdot 9-9 \cdot 3 \%$ (on a dry weight basis). Lupin species 
Table 1. Chemical composition ( $\mathrm{g} / 100 \mathrm{~g}$ dry matter) of some legume seeds (from Bagger et al. 1998)

\begin{tabular}{|c|c|c|c|c|c|}
\hline Legume seed & Protein $(N \times 6.25)$ & Crude fat & Dietary fibre & Starch & Sucrose \\
\hline Vicia faba & $26-34$ & $2-4$ & $15-24$ & $40-50$ & $2 \cdot 1-2 \cdot 3$ \\
\hline Pisum sativum & $23-31$ & $2-3$ & $15-21$ & $20-50$ & $0 \cdot 7-5 \cdot 7$ \\
\hline Lupinus luteus, L. angustifolius, L. albus & $33-42$ & $4-12$ & $25-40$ & $1-2$ & $1.5-3.5$ \\
\hline Glycine max & $38-42$ & $18-22$ & $7-15$ & $1-2$ & $4 \cdot 7-7 \cdot 6$ \\
\hline
\end{tabular}

have a special position within the Leguminosae family by containing a high amount of cell wall material in the cotyledons (in the range $7 \cdot 5-32.1 \%$ ) in the form of rather thick cell walls (Brillouet \& Riochet, 1983). This could ascribed to the high amount of galactans stored in the cell walls.

Starch content varies between genera, from negligible amounts in Glycine max to half the dry seed weight in a wild-type, round-seeded, pea (Pisum sativum) (Table 1). Mutations that affect the activities of enzymes of the starch biosynthetic pathway can profoundly affect not only starch content but also its composition. For instance, in the pea, which is one of the species that has been extensively genetically manipulated, mutations at the $r$ locus, which encodes starch-branching enzyme I, reduce starch content to $30 \%$ of dry weight and reduce the amylopectin content, whereas those at rug3, which encodes plastidial phosphoglucomutase, can completely eliminate starch (Casey, 1998).

$\alpha$-Galactosides are oligosaccharides which are not digested in the upper part of the gastrointestinal tract, due to the absence of $\alpha$-galactosidase among human endogenous enzymes, and are therefore available for bacterial fermentation in the colon. Overall $\alpha$-galactoside content is within the range of $2-10 \mathrm{~g} / 100 \mathrm{~g}$ dry matter, and stachyose is the prevalent oligosaccharide in most pulses (Phaseolus vulgaris, Pisum sativum, Lens esculenta, etc.) (Table 2). Lupin seeds seem to contain the highest concentration of $\alpha$-galactosides among grain legume species. In faba beans, mung beans, pigeon pea, and some varieties of chickpeas, verbascose is the main oligosaccharide in the seed. Raffinose content is lower than $1.5 \mathrm{~g} / 100 \mathrm{~g}$ in all pulses (Rackis, 1975; Fleming, 1981; Oboh et al. 1998). Ajugose is present in significant amounts in lupin seeds $(0 \cdot 3-2 \cdot 0 \mathrm{~g} / 100 \mathrm{~g})$ (Reddy et al. 1984). The $\alpha$-galactoside content of soyabean is quite similar to that of most pulses; for example, raffinose, stachyose and verbascose comprise $0.7-1.3,2 \cdot 2-5.4$ and $0.0-0.3 \%$, respectively, of seed dry matter (Reddy et al. 1984).

\section{Fractionation of grain legumes}

Dry and wet separation processes have been used to fractionate grain legumes for experimental purposes but also for industrial applications (Kozlowska et al. 1998; Czukor et al. 2001). Wet separation processes are used to produce high-purity protein isolates while dry separation results in enriched fractions.

In conventional wet process, for food applications, the hulls are removed because they can contain antinutritional compounds that can be released during the extraction process. The dehulled seeds are pen milled and the legume flour is pulped with an aqueous decomposing agent (generally alkaline solution) for extracting protein (Colonna et al. 1981; Gueguen, 1983; Sosulski \& McCurdy, 1987). The proteins are isolated from this extract by acidic precipitation or by ultrafiltration. The wet protein isolates are then dried. The liquid phase contains the $\alpha$-galactosides as well as many other soluble contaminants. These oligosaccharides can be further isolated in $80 \%$ ethanol. The solid phase left after protein separation is suspended in water and is screened through a series of sieves (Schoch \& Maywald, 1968; Colonna et al. 1981). The starch is recovered from the under flow fraction, with the fraction rich in cell wall material remaining on the screens. The starch isolate contains $0.04-0.40 \%$ protein, less than $4 \%$ of cell wall material and about $0 \cdot 1-1.0 \%$ of lipid as impurities. The fibre fraction contains small amounts of proteins $(4-8 \%)$ and lipids $(0.5-1.5 \%)$.

The 'dry' process consists in disintegration of the dehulled seeds on pill mill and air classification into starch and protein fractions (Sosulski, 1979; Colonna et al. 1980; Tayler et al. 1981; Sosulski et al. 1985; Sosulski \& McCurdy, 1987). The starches and dietary fibre are concentrated mostly in the light, fine fraction, and the proteins and lipids, in the heavy, coarse one. Dry processes have been carried out more successfully with grain legumes, where starch is the main storage compound rather than oil. The main advantages of air classification

Table 2. Amount of $\alpha$-galactosides in the main pulse species compared to a single main source (\%, dry matter)*

\begin{tabular}{|c|c|c|c|c|c|c|c|}
\hline & Phaseolus vulgaris & Lens esculenta & Cicer arietinum & Pisum sativam & Vicia faba & Lupinus albus & Glycine max \\
\hline Raffinose & $<0.05-0.93$ & $0.3-1.0$ & $0.4-1.2$ & $0.3-1.6$ & $0.1-0.3$ & $0.5-1.1$ & $0.5-1.3$ \\
\hline Stachyose & $0.5-4.1$ & $1 \cdot 7-3 \cdot 1$ & $2 \cdot 0-3 \cdot 6$ & $1 \cdot 3-5 \cdot 5$ & $0.7-1.5$ & $0.9-7.4$ & $2 \cdot 2-4 \cdot 3$ \\
\hline Total & $2 \cdot 6-6 \cdot 6$ & $3 \cdot 0-7 \cdot 1$ & $7 \cdot 4-7.5$ & $5 \cdot 1-8 \cdot 7$ & $3 \cdot 1-4 \cdot 2$ & $7 \cdot 4-9.5$ & $2-6$ \\
\hline
\end{tabular}

* Source: Harding et al. (1965), Cristofaro et al. (1974), Rackis (1975), Matheson \& Saini (1977), Eskin et al. (1980), Gueguen et al. (1980), lyer et al. (1980), Olson et al. (1982), Quemener \& Brillouet (1983), Reddy et al. (1984), Sathe et al. (1984), Savage \& Deo (1989), Leakey et al. (1998), Frias et al. (2001), Vidal-Valverde et al. (2001). 
are reduced energy and water consumption. However, all fractions, and especially protein fractions, are contaminated by $\alpha$-galactosides (Sahasrabudhe et al. 1981).

Because legumes have a variety of characteristics and differ, for example, in oil content, some modifications of the standard procedures have been adopted for optimizing the process for a particular legume (Nickel, 1988; Czuchajowska \& Pomeranz, 1994; Kovacs, 1996; Krikken, 1999; Dijkink \& Langelaan, 2001).

\section{Physical and chemical characteristics of fibre and starch fractions and derivatives}

The chemical structure and physico-chemical properties of starch and fibre are important for functional behaviours in food use and for diet-related health effects. Depending on the application, the use of enriched fractions may be a good alternative to high-purity isolates.

\section{Fibre fractions}

The properties of dietary fibre that influence their technofunctionality are the fibre dimensions, porosity, hydration, rheological and fat-binding properties. The colours and flavour are also of importance.

Dietary fibre preparations commercially available arise mainly from pea and soya from either the cotyledons (inner) or from the hulls (outer) (Table 3). Preparations are generally richer in dietary fibre when obtained from hulls. Indeed, preparations from cotyledons contain variable amounts of starch and protein. Inner-fibre fractions exhibit higher water retention capacity than outer fibres (Table 4). Oil-binding capacity is in the same range for both inner and outer fibres (Table 4). Inner fibres are smooth, while outer fibres have a sandy character. The inner fibre products are, in general, in the form of powder low in odour and flavour (Table 4). The outer fibres are generally available at different particle sizes. They are generally light in colour and flavour (Table 4).

Processing can be applied to improve the functional characteristics of fibre. For example, a mixture of cellulase and carbohydrase has been applied to improve the sensory properties, including the mouth-feel characteristics and smoothness of the soya fibre material (Lin Santa et al. 1996).
The composition of the dietary fibre fraction depends very much on its localization in the seed coat (outer fibre) or the cotyledons (inner fibre) (Table 5). A major difference between the inner and outer dietary fibre is the relative content of cellulosic and non-cellulosic polysaccharides. The cell walls of the cotyledons contain a range of polysaccharides, including pectic substances (about 55\%), cellulose (about 9\%) and non-starchy noncellulosic glucans (in the range 6-12\%; Brillouet \& Carré, 1983; Brillouet \& Riochet, 1983; Al-Kaisey \& Wilkie, 1992; Petterson, 1998; van Laar et al. 1999, 2000), while the seed coat contains large quantities of cellulose (ranging from 35 to $57 \%$ ) and lower amounts of hemicelluloses and pectins (Brillouet \& Riochet, 1983; Weightman et al. 1994; van Laar et al. 1999). The cell walls from the cotyledons are non-lignified.

Testa from pea and lupin species have been shown to contain a low amount of lignin. The concentrations reported were $6.6 \mathrm{mg} / \mathrm{g}$ for alcohol-insoluble residues from pea hull, and between 0.4 and $1.7 \%$ for hulls from various lupin species (Brillouet \& Riochet, 1983; Weightman et al. 1994). The lignin values were unrelated to hull colour.

\section{Starch fractions}

Most starches from grain legumes have a relatively high amylose content compared to most starches (Table 6). As a consequence their $\mathrm{X}$-ray diffraction pattern is type $\mathrm{C}$, which is considered to be intermediate between types $\mathrm{A}$ and B (Gallant et al. 1992) (Table 6). However, wrinkled peas are known to exhibit a B-type X-ray diffraction pattern which is due to its high level of amylose (Table 6).

Legume starches are kidney-like or ovoid with welldefined shells centred along an elongated hilum. Some exceptions are also known, such as the compound starch granules of the wrinkled pea, in which sphero-pyramidal units are associated (Gallant et al. 1992). Enzymatically treated pea starches (C-type starch) exhibit a characteristic similar to B-type starches, which is the presence of highly resistant and large blocklets $(4-500 \mathrm{~nm}$ diameter at the peripheral level of the granules). These blocklets would explain the resistance of $\mathrm{B}$ and $\mathrm{C}$ starch granules to hydrolysis (Gallant et al. 1992).

There is a much variability in amylose content among

Table 3. Chemical composition of some commercial dietary fibres (dry basis, \%)

\begin{tabular}{|c|c|c|c|c|c|c|}
\hline & \multicolumn{2}{|c|}{ Pea } & \multicolumn{2}{|c|}{ Soyabean } & \multicolumn{2}{|c|}{ Lupin } \\
\hline & Cotyledon* & Hull $^{\star}$ & Cotyledon† & Hull $^{\star}$ & Cotyledon* & Hull $^{*}$ \\
\hline TDF & 55 & 89 & 80 & 75 & 80 & 80 \\
\hline SDF & 14 & 7 & 21 & 10 & 8 & 8 \\
\hline Protein & 17 & 5 & 13 & 8 & 15 & 14 \\
\hline Lipid & 0.5 & 1.5 & 0.2 & 2 & 0.5 & 2 \\
\hline Available C & 23 & 2 & nd & 6 & 3 & 1 \\
\hline Mineral & 4 & 4 & 5 & 5 & 1 & 4 \\
\hline
\end{tabular}

Available C, available carbohydrates; nd, not determined; TDF, total dietary fibre; SDF, soluble dietary fibre.

* Pfoertner \& Fischer (2001).

†Dubois et al. (1993). 
Table 4. Properties of some commercial dietary fibres (from Pfoertner \& Fisher, 2001)

\begin{tabular}{|c|c|c|c|c|}
\hline Dietary fibre & Colour & Flavour & WRC & Oil retention \\
\hline \multicolumn{5}{|l|}{ Cotyledon } \\
\hline Pea & White & Neutral beany & $9-11$ & $1.5-2.0$ \\
\hline Soya & Light cream & Bland & $7-8$ & 4.0 \\
\hline Lupin & White & Nearly neutral & $8-11$ & $1 \cdot 5-2 \cdot 0$ \\
\hline \multicolumn{5}{|l|}{ Hull } \\
\hline Pea & Creamy white & Neutral & $4-5$ & $1 \cdot 8-2 \cdot 0$ \\
\hline Soya & Light tan & Neutral nutty & $3-5$ & $1.4-1.7$ \\
\hline Lupin & Creamy light & Neutral nutty & $7-8$ & $1 \cdot 6-1.7$ \\
\hline
\end{tabular}

WRC, water retention capacity.

genotypes of peas (Skrabanja et al. 1999). Indeed, the wild type contains $30 \%$ amylose whereas $r b$ and $r$ mutants, for instance, contain, respectively, 20 and $65 \%$ amylose (Bergthaller et al. 2001). According to Bergthaller et al. (2001), these same mutants differ widely in starch extractability from cotyledons in a wet milling process but also in the purity of the extracted starch, which varied from 85.3 to $97.5 \%$ (dry matter basis) for $r$ and rug 4 mutants. Temperatures of gelatinization do not seem to be significantly different from 'normal' cereal or potato starches, as they range between 55 and $97^{\circ} \mathrm{C}$ (Table 6).

The procedure of preparation of the starch can modify the characteristics of the initial starch present in the grain. Intense damaging of the starch granules can be observed in some industrial starches (Soral-Śmietana et al. $2001 b$ ). As a consequence, commercial native starches may have different properties. Apparently, Gel-Flow (native pea starch from Parrheim Foods, Canada) crystallinity, estimated by X-ray diffraction, is lower from that of Nastar (native pea starch from Cosucra S.A., Belgium) (SoralSmietana et al. 2001a,b). As a consequence, resistant starch (RS) contents of the native pea starches are different: 43 and 19\%, respectively, for Nastar and Gel-Flo. The latter starch exhibited slightly higher water and oil adsorption capacities than the former (Soral-Śmietana et al. 2001a,b).

Starch has also been isolated from chickpeas. One of the starches that has been isolated seems to have similarities with native maize starch, with a relatively high temperature of gelatinization $\left(67^{\circ} \mathrm{C}\right)$, whereas another had a low temperature of gelatinization $\left(60^{\circ} \mathrm{C}\right)$ (Meares et al. 2001).

Ionic (cationic, anionic and amphoteric) pea starch derivatives have been developed to correspond to the demand of industries in various non-food applications. The introduction of ionic substituents into the starch molecules significantly affects their physico-chemical properties, such as gelatinization temperature, swelling characteristics, solubilization and iodine complexation (Lewandowicz et al. 2001).

\section{$\alpha$-Galactosides}

$\alpha$-Galactosides are derived from sucrose and contain 1-3 units of galactose linked by $\alpha-1,6$ linkages. They are highly soluble in aqueous media and very rapidly fermented by colonic microflora. The role of $\alpha$-galactosides seems to be multiple, as they are an energy source for the plant and disappear during germination. They are stored by seeds during the final stage of ripening when they dry. They seem to help protect against abiotic stresses such as cold and desiccation (Jones et al. 1998). Some agricultural factors seem to affect $\alpha$-galactoside content in faba bean seeds. For example, the concentration of stachyose and verbascose can decrease when optimal irrigation is applied (Szukala et al. 2001).

Soaking, the most common treatment for partial elimination of $\alpha$-galactosides from grains, becomes more efficient when bicarbonate is added, due to the greater

Table 5. Sugar composition of the cell walls (\% of total cell wall sugars)

\begin{tabular}{|c|c|c|c|c|c|c|}
\hline & \multicolumn{2}{|c|}{ Pea } & \multicolumn{2}{|c|}{ Soyabean } & \multicolumn{2}{|c|}{ Lupin } \\
\hline & Cotyledon* & Hull† & Cotyledon* & Hull† & Cotyledon $\ddagger$ & Hull \\
\hline Rha & $2 \cdot 0$ & $1 \cdot 1$ & 1.8 & $1 \cdot 2$ & 1.0 & 0.5 \\
\hline Fuc & 0.9 & 0.2 & 3.1 & 0.5 & nd & nd \\
\hline Ara & $42 \cdot 7$ & $5 \cdot 2$ & 17.9 & 7.6 & $13 \cdot 3$ & 8.4 \\
\hline Xyl & 4.5 & $10 \cdot 8$ & $5 \cdot 1$ & $12 \cdot 6$ & 5.5 & 21.6 \\
\hline Man & nd & 0.2 & 1.6 & $7 \cdot 2$ & 0 & 1.3 \\
\hline Gal & 5.4 & 1.5 & 34.4 & 3.7 & $62 \cdot 4$ & 1.8 \\
\hline Glc & $25.9(57) \S$ & 64.0 & $13 \cdot 8$ & 53.5 & $9.5(9)$ & $56 \cdot 5$ \\
\hline Uronic acid & 18.7 & $17 \cdot 1$ & $22 \cdot 3$ & $13 \cdot 6$ & 8.2 & $10 \cdot 0$ \\
\hline
\end{tabular}

Rha, rhamnose; Fuc, fucose; Ara, arabinose; Xyl, xylose; Man, mannose; Gal, galactose; Glc, glucose; nd, not determined.

* Brillouet \& Carre (1983)

† Lo (1989).

$\ddagger$ Brillouet \& Riochet (1983).

$\S$ Percentage of glucose released by mild acid hydrolysis corresponding to non-cellulosic glucose. 
Table 6. Some characteristics of legume starches compared to other common starches

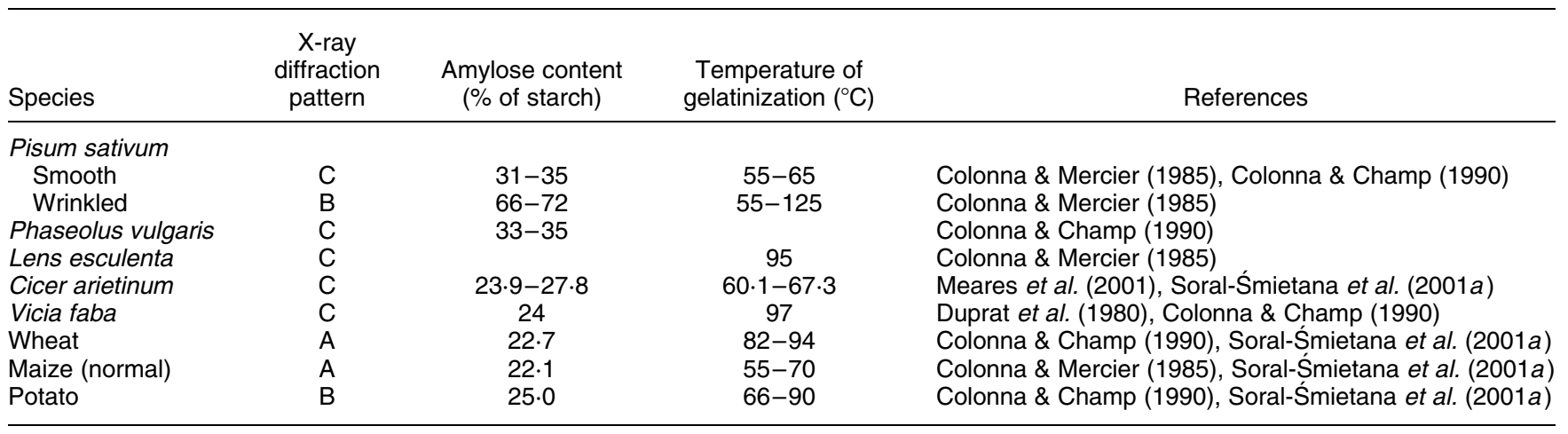

permeability obtained by partial solubilization of the cell wall (Ibrahim, 2002).

The addition of $\alpha$-galactosidase (of commercial origin) lowered $\alpha$-galactoside content in lentil and pea flours (Frias et al. 2001). Germination is one of the most efficient biological treatments for removing $\alpha$-galactosides. After germination for $48 \mathrm{~h}$ at $20^{\circ} \mathrm{C} 40-60 \%$ of pea oligosaccharides disappeared (Dostalova et al. 2001). The combined effect of germination and microwave treatment and/or conventional drying further decreased the $\alpha$-galactoside content of germinated peas (Kadlec et al. 2001).

De Lumen (1992) has suggested the use of biotechnological and genetic engineering approaches for $\alpha$-galactoside removal. Price et al. (1988) and Leakey (1994) considered that breeding against flatulence could be useful.

Instead of eliminating $\alpha$-galactosides during food preparation, it is possible to prevent flatus by different means. Hall et al. (1981) found that orally administrated activated charcoal was effective in preventing a large increase in the number of flatus events and raised normal breath hydrogen concentrations following a gas-producing meal. However, according to Potter et al. (1985), activated charcoal does not seem to influence gas formation after ingestion of a baked bean meal. An oral $\alpha$-galactosidase solution (Beano) has also been proposed to prevent flatus (Ganiats et al. 1994) after consumption of pulses.

\section{Main uses of fibre and starch fractions}

\section{Fibre fractions}

Inner fibres are generally used as texturing or bulking agents. The high water-binding capacity, fat-binding and texturing effect allow the control of migration in food preparation by providing stability towards industrial manufacturing and storage processes as well as desirable texture. They may, in many cases, replace food additives, offering the benefit of a 'clean labelling'. The dosage rate is $1-5 \%$ of the final product weight. They are used in bread and baked goods, particularly biscuits. They can also be used to enrich mousses, jellies and drinks to provide tasty desserts. These could be part of the diet of dysphagic groups and other groups who might otherwise have low fibre intake. Outer fibre is used primarily to enrich the fibre content of food without modifying the technical properties of the end products. It finds applications in bakery and extruded products, snacks, cereals or diet specialities.

\section{Starch fractions}

Starch from peas is used in deep-frozen dishes, dressings, extruded bakery products, instant soups and puddings. It can also been used for non-food applications (the paper and board industry, detergent manufacture, water-treatment industry, textiles, plastics and pharmaceutical production), as it is the case for maize and potato starches (Kozlowska et al. 1998). The production of legume starches is still small compared the overall production of starch, which is over 6 millions tonnes each year (Kozlowska et al. 1998). However, the characteristics of legume starches, and particularly their amylose content, offer a large potential for new applications, both in non-food uses and in human nutrition.

Wrinkled-pea starch seems to be favourable for the functional properties of bioplastics (Funke \& Lindhauer 1994; Colonna et al. 1995). Legume starches also have potential in agrochemical and pharmaceutical industries as an encapsulation agent, binding material to make up tablets, or a disintegrating agent (Kozlowska et al. 1998). The nutritional potential of legume starches will be discussed below.

\section{$\alpha$-Galactosides}

Due to their characteristics, it is highly probable that prebiotic properties of $\alpha$-galactosides will be confirmed in the future, as has been demonstrated for fructooligosaccharides, for instance. These properties will be discussed below.

\section{Is there a potential use of fibre and starch fractions for health?}

There is a large literature on the nutritional aspects of grain legumes, including the digestibility of main nutrients (mainly proteins, starch and dietary fibre), colonic fermentation, post-prandial glycaemia and insulinaemia and some data on lipid metabolism. These observations are, for the most part, very positive and would tend to demonstrate that grain legumes should be promoted as part of a healthy diet. We wonder if such beneficial effects could be, at least 
Table 7. Physiological effects of fibre preparation obtained from grain legumes

\begin{tabular}{|c|c|c|c|c|c|c|}
\hline Source of dietary fibre & Patients or animals & Dose & $\begin{array}{l}\text { Adaptation } \\
\text { period }\end{array}$ & Results & Remarks & References \\
\hline \multicolumn{7}{|c|}{ Glucose response and tolerance } \\
\hline $\begin{array}{l}\text { Soya cotyledon } \\
\text { fibre }\end{array}$ & Obese NIDDM patients & $10 \mathrm{~g} / \mathrm{d}$ & $\begin{array}{l}\text { Post-prandial } \\
\text { study }\end{array}$ & Improved glucose tolerance & & Tsai et al. (1987) \\
\hline $\begin{array}{l}\text { Pea cotyledon } \\
\text { fibre }\end{array}$ & Healthy subjects & $33 \mathrm{~g} / \mathrm{d}$ & 2 weeks & $\begin{array}{l}\text { No effect on glycaemic response } \\
\text { Lower PP insulin }\end{array}$ & $\begin{array}{l}\text { DF added to a normal } \\
\text { diet }\end{array}$ & Sandström et al. (1994) \\
\hline \multirow[t]{2}{*}{ Soya hulls } & Healthy subjects & $26 \mathrm{~g} / \mathrm{d}$ & $30 \mathrm{~d}$ & Improved glucose tolerance & & Munoz et al. (1979) \\
\hline & NIDDM patients & $26 \mathrm{~g}$ and $52 \mathrm{~g} / \mathrm{d}$ & 4 weeks & Improved glucose tolerance & & Mahalko et al. (1984) \\
\hline \multirow[t]{3}{*}{ Soya fibre (?) } & NIDDM patients & $40 \mathrm{~g} / \mathrm{d}$ & 4 and 12 weeks & $\begin{array}{l}\text { Improved glucose tolerance } \\
\text { Insulin levels unchanged }\end{array}$ & & Madar et al. (1988) \\
\hline & & & & $\begin{array}{l}\text { Decreased fasting glucose (12 weeks) } \\
\text { (when } 130 \mathrm{mg} / 100 \mathrm{ml} \text { at time } 0 \text { ) }\end{array}$ & $\begin{array}{l}\text { SF in bread more efficient } \\
\text { than powder }\end{array}$ & \\
\hline & ob/ob obese mice & $11-12 \%$ of the diet & 90 and $180 \mathrm{~d}$ & $\begin{array}{l}\text { Decreased fasting glucose } \\
\text { Improved glucose tolerance } \\
\text { Decreased fasting insulin }\end{array}$ & & Madar et al. (1985) \\
\hline \multirow[t]{2}{*}{ Pea hulls } & Healthy subjects & $10 \mathrm{~g} \mathrm{DF}$ & $\begin{array}{l}\text { Post-prandial } \\
\text { study }\end{array}$ & No effect on glucose and insulin response & $\begin{array}{l}\text { DF added to a complex } \\
\text { meal }\end{array}$ & Dubois et al. (1993) \\
\hline & & $30 \mathrm{~g}(15 \mathrm{~g} \mathrm{DF})$ & $\begin{array}{l}\text { Post-prandial } \\
\text { study }\end{array}$ & Lower glucose and insulin response & DF added to a test meal & Hamberg et al. (1989) \\
\hline \multicolumn{7}{|l|}{ Lipaemia } \\
\hline \multirow{4}{*}{$\begin{array}{l}\text { Soya cotyledon } \\
\text { fibre }\end{array}$} & Hypercholesterolaemic patients & $25 \mathrm{~g} / \mathrm{d}$ & 9 weeks & Lowering effect on cholesterol (total, LDL) & & Lo et al. (1986) \\
\hline & Obese NIDDM patients & $10 \mathrm{~g} / \mathrm{d}$ & Post-prandial & Decreased rise of pp plasma TG & & Tsai et al. (1987) \\
\hline & $\begin{array}{l}\text { Normocholesterolaemic, mildly or } \\
\text { moderately hypercholesterolaemic }\end{array}$ & & study & No effect on cholesterolaemia & & $\begin{array}{l}\text { Tsai et al. (1983), } \\
\text { Schweizer et al. (1983) }\end{array}$ \\
\hline & patients & & & Decreased cholesterolaemia & & $\begin{array}{l}\text { Shorey et al. (1985), } \\
\text { Lo \& Cole (1990) }\end{array}$ \\
\hline $\begin{array}{l}\text { Pea cotyledon } \\
\text { fibre }\end{array}$ & Healthy subjects & $33 \mathrm{~g} / \mathrm{d}$ & 2 weeks & $\begin{array}{l}\text { Decreased fasting and PP plasma TG } \\
\text { No effect on fasting cholesterolaemia } \\
\text { (total, LDL and } \mathrm{HDL} \text { ) }\end{array}$ & DF added to a normal diet & Sandström et al. (1994) \\
\hline \multirow[t]{3}{*}{ Soya hulls } & Healthy subjects & $26 \mathrm{~g} / \mathrm{d}$ & $28-30 d$ & Decreased cholesterolaemia & Typical American diet & Munoz et al. (1979) \\
\hline & NIDDM patients & $52 \mathrm{~g} / \mathrm{d}$ & 4 weeks & $\begin{array}{l}\text { No effect on plasma TG and TC } \\
\text { Increased HDL-cholesterol }\end{array}$ & & Mahalko et al. (1984) \\
\hline & Rats & $5 \mathrm{~g} / 100 \mathrm{~g}$ & 4 weeks & $\begin{array}{l}\text { Lower plasma and tissue TC } \\
\text { (LDL and VLDL) and TG } \\
\text { No effect on HDL-cholesterol }\end{array}$ & Hypercholesterolaemic diet & Uberoi et al. (1992) \\
\hline Pea hulls & Normolipaemic subjects & $10 \mathrm{~g}$ & $\begin{array}{l}\text { Post-prandial } \\
\text { study }\end{array}$ & $\begin{array}{l}\text { No effect on PP plasma TG } \\
\text { Decreased PP cholesteroaemia } \\
\text { (mostly esterified cholesterol) }\end{array}$ & $\begin{array}{l}\text { High-fat, high-cholesterol } \\
\text { diet }\end{array}$ & Dubois et al. (1993) \\
\hline
\end{tabular}


$30 \%$ of the diet

3 weeks

Enhanced absorption of $\mathrm{Ca}$ and $\mathrm{Mg}$ in the

Large intestine physiology Soya cotyledons fibre

Healthy subjects

$17 d$

$21 \mathrm{~g} / \mathrm{d}$

3 weeks

Healthy subjects

Constipated, tube-fed

non-ambulant patien

Diarrhoeic, tube-fed

non-ambulant patients

Infants with acute diarrhoea

(>6 months old

Soya hulls

Healthy subjects

Healthy subjects

$30-60 \mathrm{~g} / \mathrm{d}$

$10 d$

$20-22 \cdot 3 \mathrm{~g} / \mathrm{d}$

2 weeks

$21 \mathrm{~g} / \mathrm{lper} \mathrm{d}$

$15 d$

$0.7 \mathrm{~g} \mathrm{DF}$. D per $\mathrm{kg}$

infant's weight

$26 \mathrm{~g} / \mathrm{d}$

$10 d$

$30 \mathrm{~g} / \mathrm{d}$

$28-30 d$

Healthy subjects

$15 \mathrm{~g} / \mathrm{d}$

$15 d$

Rats

$5 \%$ of the diet large intestine

DM and energy

increased stool weight

No effect on TT and stool frequency

Increased stool weight and frequency

Decreased TT

Reduction of the duration of the diarrhoe

Increased number of stools per week

Increased stool wet weight

No effect in subjects with short TT

No effect of fine particles $(<100 \mu \mathrm{m})$ on

colonic motor profile

Coarse particles decrease mean $T$
Increased stool weigh

No reduction of diarrhoea

No effect of fine particles $(<100 \mu \mathrm{m})$ on
Tsai et al. (1983)

Levrat et al. (1991)

Tsai et al. (1983)

Schweizer et al. (1983)

Slavin et al. (1985)

Fischer et al. (1985)

Dobb \& Towler, (1990)

Vanderhoof et al. (1997)

Munoz et al. (1979)

Cherbut et al. (1991)

Guédon et al. (1996)

Focant et al. (1990)

DF, dietary fibre; DM, dry matter; NIDDM, non-insulin-dependent diabetes mellitus; PP, post-prandial; SF, soluble fibre; TC, total cholesterol; TG, triacylglycerols; TT, transit time; nm, not mentioned in the paper. 
partly, attributed to the starch and/or the dietary fibre (total or one specific fraction) and thus if purified or semi-purified starches and fibres could be of interest for health.

\section{Fibre fractions}

The literature on isolated dietary fibre from legume seeds is very scarce, and mainly concerns soya and, to a lesser extent, pea fibres. Most of these studies are summarized in Table 7. It is very difficult to draw definitive conclusions from these data as doses of fibre, duration and design of studies are not comparable. However, there are the following tendencies:

1. according to several studies, consumption of fibre from pea or soya would improve glucose tolerance;

2. some of the studies indicated a positive effect of soya and pea fibre on cholesterolaemia and/or postprandial triglyceridaemia but others did not show any effect;

3. most studies, performed with healthy subjects, showed an increased of the stool weight when they ate soya or pea fibres (usually more than $20 \mathrm{~g} / \mathrm{d}$ ).

Part of the physiological effects of these fibres could be explained by their fermentation pattern. The fermentability of fibres has been studied in vitro in batch systems (Cherbut et al. 1991; Titgemeyer et al. 1991; Bourquin et al. 1993; Barry et al. 1995; Cloutour, 1995; Guillon et al. 1995; Casterline et al. 1997; Lebet et al. 1998; Van Laar et al. 2000). The results showed that fibres from cotyledons were highly degraded (percentage of fermentability: 57$91 \%$ ) while fibres from hulls were fermented only to a limited extent (percentage of fermentability: 22-41\%). Acetate was always the major short-chain fatty acid (SCFA) of the medium (about 47-89\%), followed by propionic (7$45 \%)$ and then butyric acid (6-22\%), the other acids being present in very low concentration. Compared to other sources of highly fermented dietary fibre such as pectins, sugarbeet or apple fibres, soyabean fibre (inner fibre) fermentation was generally characterized by relatively high proportions of propionic acid and butyric acid (Table 8). In vivo in rats, Levrat et al. (1991) reported that fermentation of soya fibre yielded a high level of propionate and low level of butyrate in the caecum. In vivo, the increase in SCFA in the caecum of rats fed soyabean fibre was accompanied by an increase in SCFA absorption (Levrat et al. 1991; Key \& Mathers, 1993). The caecum was enlarged and the wall hypertrophied. There was a moderate and transitory induction of enzymes (ornithine decarboxylase and thymidine kinase) involved in proliferative processes of the colonic epithelium (Levrat et al. 1991). Nevertheless, the degree of induction of the enzymes was less than that reported for other fermentable substrates (Calvert et al. 1989).

\section{Starch fractions}

Bioavailability of native and cooked starches from grain legumes is known to be relatively poor compared to most cereal starches (Hildebrandt \& Marlett, 1991; Granfeldt et al. 1992; Björck et al. 1994; Tovar, 1996; Brighenti et al. 1998; Seewi et al. 1999). When inside an intact grain, starch granules are entrapped inside the cell wall, making them unavailable in the upper part of the digestive tract unless these cell walls are disrupted during the preparation of the food or by chewing. The low bioavailability of these starches is also explained by the starch itself, which is relatively rich in amylose. Indeed, (1) when raw, it is more resistant than most cereal starches due to its higher crystallinity; (2) it needs a higher temperature to be fully gelatinized and has a higher risk of being insufficiently cooked; (3) after appropriate cooking, it has a higher capacity to retrograde than most starches with a lower content in amylose. This retrogradation is a recrystallization of the linear chains of amylose and, later on, of the branched chains of amylopectin. As a consequence, part of these starches can be 'resistant' to digestion in the small intestine (Noah et al. 1998) and ferment in the colon, producing SCFA and gases $\left(\mathrm{CO}_{2}, \mathrm{H}_{2}\right.$ and, in some, $\left.\mathrm{CH}_{4}\right)$. The fraction that is digested in the small intestine is slowly available and contributes to the low glycaemic index of the wholegrain legumes. The resistant starch fraction seems to be interesting due to the production of a large amount of butyrate (one of the three main short-chain fatty acids) during colonic fermentation. This nutrient is the

Table 8. Short-chain fatty acid production during in vitro fermentation of substrates ( $\mathrm{mmol} / \mathrm{g}$ original substrate dry matter)

\begin{tabular}{|c|c|c|c|c|c|}
\hline \multirow[b]{2}{*}{ Substrate } & \multirow[b]{2}{*}{ Total SCFA (mmole/g) } & \multicolumn{3}{|c|}{ Molar ratio } & \multirow[b]{2}{*}{ Reference } \\
\hline & & Acetate & Propionate & Butyrate & \\
\hline Better basic 872 oat fibre & 0.42 & 61.9 & $16 \cdot 7$ & $21 \cdot 4$ & Bourquin et al. (1993) \\
\hline Bleached oat hull & 0.37 & $87 \cdot 3$ & $11 \cdot 6$ & $1 \cdot 1$ & Titgemeyer et al. (1991) \\
\hline Oat bran & 2.66 & $49 \cdot 6$ & $36 \cdot 1$ & $14 \cdot 3$ & Casterline et al. (1997) \\
\hline Fibrim $^{\circledR}$ soya fibre & $5 \cdot 75$ & 64.5 & $19 \cdot 5$ & $16 \cdot 0$ & Bourquin et al. (1993) \\
\hline Fibrim ${ }^{\circledR}$ soya fibre & 1.94 & 71.4 & $20 \cdot 6$ & $8 \cdot 1$ & Titgemeyer et al. (1991) \\
\hline Fibrim ${ }^{\circledR}$ soya fibre & 2.55 & $46 \cdot 7$ & $44 \cdot 7$ & $8 \cdot 6$ & Casterline et al. (1997) \\
\hline Duo sugarbeet fibre & $1 \cdot 16$ & $92 \cdot 6$ & $6 \cdot 6$ & 0.8 & Titgemeyer et al. (1991) \\
\hline Apple fibre & 1.56 & $67 \cdot 9$ & $26 \cdot 3$ & $5 \cdot 8$ & Casterline et al. (1997) \\
\hline Arabic gum & $8 \cdot 19$ & $65 \cdot 7$ & $22 \cdot 8$ & $11 \cdot 3$ & Bourquin et al. (1993) \\
\hline Arabic gum & 6.94 & $66 \cdot 2$ & $25 \cdot 3$ & 8.4 & Casterline et al. (1997) \\
\hline Centara II pea fibre & 0.76 & $74 \cdot 1$ & $16 \cdot 7$ & $9 \cdot 2$ & Titgemeyer et al. (1991) \\
\hline Centara III pea fibre & 1.99 & $73 \cdot 4$ & $21 \cdot 1$ & $5 \cdot \overline{5}$ & Casterline et al. (1997) \\
\hline
\end{tabular}

SCFA, short-chain fatty acid. 
main fuel of the colonocyte and seems to play a role in the prevention in a number of colonic diseases, including colon cancer.

Recently Soral-Śmietana et al. (2001a) proposed using native pea starches to produce resistant starches. They obtained an RS preparation from two commercial peas starches (Nastar and Gel-Flo) with 38\% RS (\% dry matter), the initial native pea starches containing respectively 43 and $19 \%$ RS (\% dry matter).

Pure pea starch (NASTAR, Cosucra BV, Rosendaal, The Netherlands) elicited less hyperglycaemia ( $-47 \%)$, hyperinsulinaemia $(-54 \%)$, and C-peptide secretion $(-37 \%)$ as compared to corn starches (modified and unmodified) $(P<0.05)$ in healthy subjects (Seewi et al. 1999). No differences in flatulence nor breath hydrogen were observed between both starches, suggesting no significant differences in RS content between the two starches.

In a study on pigs, van der Meulen et al. (1997) concluded that ileal digestibilities of native maize and pea starches were equal, but that the rate of appearance of glucose in the portal vein was higher for maize starch. Net portal glucose flux was lower for pea starch, but after $8 \mathrm{~h}$ post-prandially, portal glucose flux was significantly higher than with maize starch. Net portal SCFA flux, being higher with pea starch than with maize starch, did not apparently confirm the results of ileal digestibility, but that could be explained by different uptakes of SCFA by the colonic mucosa as already suspected with other RS (Martin et al. 2000).

Mung bean (Phaseolus aureus) and waxy maize starches were incorporated in the diet of rats to provide, respectively, a low- and a high-glycaemic-index (GI) diet (Kabir et al. 2000). After 12 weeks, the group fed the low-GI food had higher plasma leptin and ob mRNA than the other group, but no effect was observed on food intake, basal plasma glucose, insulin or triacylglycerols. It was suggested that leptin sensitivity was increased in the 'high-GI group' and that this step might precede weight gain and increase in fat mass. Earlier, the same group (Kabir et al. 1998) showed that the high-GI diet stimulated fatty acid synthase activity and lipogenesis, and might have undesirable long-term metabolic effects.

The same mung bean starch has been compared with corn starch and glucose in humans to quantify the rate of net post-hepatic appearance of glucose after ingestion of both starches (Lang et al. 1999). Glycaemic indices of maize and mung bean starches were respectively $95 \pm 18$ and $51 \pm 13$. Post-hepatic appearance of glucose from glucose, corn and mung bean starches represented respectively $79.4 \pm 5 \cdot 0,72.6 \pm 4.0$ and $35.6 \pm 4.6 \%$ of the glucose load after $4.5 \mathrm{~h}$ post-prandially. This big difference has been attributed to the fact that mung bean starch contains about $11 \%$ of $\mathrm{RS}$, and to a long absorption period of mung bean starch which was probably not finished $4.5 \mathrm{~h}$ after the meal.

Recently, Fukushima et al. (2001) observed the lowering of serum total cholesterol in rats by starches of two different varieties of beans (Phaseolus vulgaris) $(15 \mathrm{~g} / \mathrm{kg})$. The total cholesterol:HDL-cholesterol ratio in these bean starch groups was also significantly lower than in the control group (maize starch) at the end of the 4-week feeding period. This effect was attributed to the enhancing effect of RS on the hepatic LDL receptor mRNA level.

The pattern of large intestine SCFA after consumption of starchy grain legumes has been confirmed to be rich in butyrate. Indeed, Key \& Mathers (1993) observed a considerable increase in butyrate between 1 and $3 \mathrm{~d}$ and up to $14 \mathrm{~d}$ of adaptation of rats to a diet containing cooked $P$. vulgaris. No RS was recovered in the faeces of the animal, showing the complete colonic fermentation of this fraction.

\section{$\alpha$-Galactosides}

Due to their high fermentability, $\alpha$-galactosides induce the production of gases (mainly $\mathrm{CO}_{2}, \mathrm{H}_{2}$ and, in some populations, $\mathrm{CH}_{4}$ ) responsible for the digestive discomfort related to pulse consumption. These oligosaccharides are quite characteristic of grain legumes and are present in all species, with large variabilities among different varieties. Although $\alpha$-galactosides are claimed to be solely responsible for flatulence in soyabeans or pulses, the flatulence activity of some grain legumes (e.g. smooth-seeded field peas) may also be due to indigestible oligosaccharides and cell wall fibre constituents (Fleming, 1981).

Besides causing digestive discomfort in most populations, flatus production may be a more acute problem in individuals with colonic pathologies such as irritable bowel syndrome. For instance, the local bean diet has been identified as one of the most common aggravating factors of irritable bowel syndrome in Nigerians (Atoba, 1988). Flatus production needs to be lowered in these patients by reducing consumption of fermentable carbohydrates such as beans or lentils (Friedman, 1991).

For most of the population, it might seem desirable to remove $\alpha$-galactosides from pulses by technological or genetic means. However, these non-digestible oligosaccharides have been identified as prebiotic agents (Van Loo et al. 1999), i.e. food ingredients potentially beneficial to the health of consumers. At the present time in Europe, the main prebiotics are inulin-type fructans, characterized by the presence of fructosyl units bound to the $\beta-2,1$ position of sucrose. Prebiotics escape enzymatic digestion in the upper gastrointestinal tract and enter the caecum without change to their structure. None are excreted in stools, which indicates that they are fermented by colonic flora to produce a mixture of SCFA (acetate, propionate and butyrate), L-lactate, $\mathrm{CO}_{2}$ and $\mathrm{H}_{2}$. Their stimulation of bifidobacteria may have several beneficial implications for health:

1. Potential protective effects against colorectal cancer and infectious bowel diseases through inhibition of putrefactive (Clostridium perfringens) and pathogenic bacteria (Escherichia coli, salmonella, Listeria sp. and shigella), respectively. The effects of prebiotics on colon carcinogenesis and tumour growth have been evaluated in animals (mostly on azoxymethane- or dimethylhydrazine-treated rats), and development of colonic aberrant crypt foci (ACF) is the marker most often described. ACF are putative preneoplastic lesions 
from which adenomas and carcinomas may develop in the colon (Reddy, 1999).

2. Improvement of carbohydrate and lipid metabolism. This possibility has gained support from the observation that dietary oligofructosaccharides cause suppression of hepatic triacylglycerol and VLDL synthesis in animals, resulting in marked reductions in triacylglycerol and, to a lesser extent, cholesterol levels (Taylor \& Williams, 1998).

3. Providing fibre-like properties by decreasing renal nitrogen excretion.

4. Increasing the availability of essential minerals.

5. Acting as a low cariogenic factor.

It has been shown clearly in human volunteers that nondigestible oligosaccharides, particularly fructooligosaccharides, stimulate the growth of bifidobacteria selectively, modifying the composition of the colonic microbiota significantly (Roberfroid, 1997).

These potentially beneficial effects have been largely studied in animals, but have not really been tested in humans (Roberfroid, 1998; Grizard \& Barthomeuf, 1999; van Loo et al. 1999). Human clinical trials are likely to broaden our insight concerning the importance of prebiotics in health and disease.

Although prebiotic effects have been demonstrated extensively with oligofructose, fructooligosaccharides and inulin, there is no evidence (a lack of studies) of such effects with $\alpha$-galactosides. However, like low molecular weight fructans, they are quickly fermented (Bradburn et al. 1993) in the colon and could be expected to have beneficial properties similar to those of fructooligosaccharides.

\section{Conclusion}

Apart from being eaten as a vegetable, grain legumes can be considered as a source for raw material for the processing industry. Legume starch and fibre both have useful functional properties and can be used readily in food products. Procedures have been developed for isolating these fractions. Legume starch has unique properties, having a good stability to high temperature and high point viscosity compared with equivalent cereal or tuber starch. The technofunctional properties can be further improved by starch processing, including chemical and biotechnological methods. Moreover, mutant genes affecting starch synthesis may enlarge the spectrum of starch that could suit a wide range of food and non-food applications. The fibre fraction from the seed embryo has excellent water hydration properties that could be utilized to structure food and replace fat in areas such as confectionery, dressings or meat.

Starch and fibre can also be proposed as ingredients for their beneficial health effects. Legume seed starch is a source of RS, which seems to be interesting for the production of a large amount of butyrate on its fermentation by colonic bacteria. Fibre provides a broad range of positive effects, both physiological and metabolic, at least in subjects suffering from disorders. These effects are related to the source of fibre (from cotyledon or hull), are dose related and depend on the form in which it is ingested.

Scientific research must be undertaken to substantiate the potential long-term positive effects of legume starch and fibre ingestion on health, in both normal individuals and subjects suffering from disorders. Fundamental knowledge of the behaviour of starch and fibre fractions in complex food systems is still required in order to be able to propose ingredients and adaptations to formulations for appetizing foods with good nutritional properties.

\section{References}

Al-Kaisey MT \& Wilkie KCB (1992) The polysaccharide of agricultural lupin seeds. Carbohydrate Research 227, 147-161.

Atoba MA (1988) Irritable bowel syndrome in Nigerians. Digestive Diseases Sciences 33, 414-416.

Bagger CL, Bjergegaard C, Sorensen H, Sorensen JC \& Sorensen S (1998) Biorefining lupin seeds to obtain high value protein concentrates and isolates. In Proceedings of the 3rd European Conference on Grain Legumes, Valladolid, Spain, 14-19 November, pp. 48-49 [AEP, editors]. Paris: AEP Editions.

Barry JL, Hoebler C, MacFarlane GT, MacFarlane S, Mathers JC, Reed KA, Mortensen PB, Nordgaard I, Rowland IR \& Rumney CJ (1995) Estimation of the fermentability of dietary fibre in vitro: a European interlaboratory study. British Journal of Nutrition 74, 303-322.

Bergthaller W, Themeier H \& Lepa R (2001) Extraction of starch and protein from pea mutant cotyledon breaks in a pilot plant by applying neutral media and enzyme technology. In Proceedings of the 4th European Conference on Grain Legumes, Cracow, Poland, 8-12 July, pp. 386-387 [AEP, editors]. Paris: AEP Editions.

Björck I, Granfeldt Y, Liljeberg H, Tovar J \& Asp NG (1994) Food properties affecting the digestion and absorption of carbohydrates. American Journal of Clinical Nutrition 59, 699S-705S.

Bourquin LD, Titgemeyer EC, Fahey GC \& Garleb KA (1993) Fermentation of dietary fibre by human colonic bacteria: disappearance of short chain fatty acid production from, and potential water holding capacity of, various substrates. Scandinavian Journal of Gastroenterology 28, 249-255.

Bradburn DM, Mathers JC, Gunn A, Burn J, Chapman PD \& Johnston ID (1993) Colonic fermentation of complex carbohydrates in patients with familial adenomatous polyposis. Gut 34, 630-636.

Brighenti F, Casiraghi MC \& Baggio C (1998) Resistant starch in the Italian diet. British Journal of Nutrition 80, 333-341.

Brillouet J-M \& Carré B (1983) Composition of cell walls from cotyledons of Pisum sativum, Vicia faba and Glycine max. Phytochemistry 22, 841-847.

Brillouet J-M \& Riochet D (1983) Cell wall polysaccharides and lignin in cotyledons and hulls of seeds from variuous lupin (Lupinus L.) species. Journal of Science and Food Agriculture 34, 861-868.

Calvert RJ, Otsuka M \& Satchitchanadam S (1989) Consumption of raw potato starch alters intestinal function and colonic cell proliferation in the rat. Journal of Nutrition 19, 1610-1616.

Casey R (1998) The seed composition of grain legumes. In Proceedings of the 3rd European Conference on Grain Legumes, Valladolid, Spain, 14-19 November, pp. 73-75 [AEP, editors]. Paris: AEP Editions.

Casterline JL, Oles CJ \& Kuoh Y (1997) In vitro fermentation of various food fiber fractions. Journal of Agricultural and Food Chemistry 45, 2463-2467. 
Cherbut C, Salvador V, Barry J-L, Doulay F \& Delort-Laval J (1991) Dietary fibre effects on intestinal transit in man: involvement of their physico-chemical properties. Food Hydrocolloids 5, 15-22.

Cloutour F (1995) Caractéristiques des fibres alimentaires: influence sur leur fermentation in vitro par la flore digestive de l'homme (Characteristics of food fibres: influence of the human digestive flora on their fermentation in vitro ). $\mathrm{PhD}$ dissertation, Faculté des Sciences et Techniques, Université de Nantes.

Colonna P \& Champ M (1990) Significance of starch damage in feeds. Sciences des aliments 10, 877-897.

Colonna P, Gallant D \& Mercier C (1980) Pisum sativum and Vicia faba carbohydrates: studies of fractions obtained after dry and wet protein extraction processes. Journal of Food Science 45, 1629-1636.

Colonna P, Gueguen J \& Mercier C (1981) Pilot scale preparation of starch and cell wall material from Pisum sativum and Vicia faba. Sciences des Aliments 1, 415-426.

Colonna P, Lourdin D, Dellavalle G \& Buléon A (1995) Importance of amylose in non food uses of pea starches for thermoplastic materials. In Proceedings of the 2nd European Conference on Grain Legumes, Copenhagen, Denmark, pp. 354-355 [AEP, editor]. Paris: AEP Editions.

Colonna P \& Mercier C (1985) Gelatinization and melting of maize and pea starches with normal and high-amylose genotypes. Phytochemistry 24, 1667-1674.

Cristofaro E, Mottu F \& Wuhrmann JJ (1974) Involvement of the raffinose family of oligosaccharides in flatulence. In Sugars in Nutrition, pp. 313-336 [HL Sepple and KW McNutt, editors]. New York: Academic Press.

Czuchajowska Z \& Pomeranz Y (1994) Process for fractionating legumes to obtain pure starch and a protein concentrate. US patent number: US5364471, University of Washington.

Czukor B, Bogracheva T, Cserhalmi Z, Fornal J, SchusterGajzágó I, Kovacs ET, Lewandowicz G \& Soral-Smietana M (2001) Processing. In Carbohydrates in Grain Legume Seed; Improving Nutritional Quality and Agronomic Characteristics, pp. 89-116 [CL Hedley, editor]. Wallingford: CAB International.

De Lumen BO (1992) Molecular strategies to improve protein quality and reduce flatulence in legumes: a review. Food Structure 11, 33-46.

Dijkink BH \& Langelaan B (2001) Air classification of different pea genotypes. In Proceedings of the 4th European Conference on Grain Legumes, Cracow, Poland, 8-12 July, pp. 132-133 [AEP, editors]. Paris: AEP Editions.

Dobb GJ \& Towler SC (1990) Diarrhoea during enteral feeding in the critically ill: a comparison feeds with and without fibre. Intensive Care Medicine 16, 252-255.

Dostalova J, Zatopkova M, Borovickova L, Skulinova M, Valentova H, Pokorny J, Hosnedl V \& Kadlec P (2001) Possibilities of higher utilization of grain legumes in human nutrition. In Proceedings of the 4th European Conference on Grain Legumes, Cracow, Poland, 8-12 July, p. 415 [AEP, editor]. Paris: AEP Editions.

Dubois C, Cara M, Armand M, Borel P, Senft M, Portugal H, Pauli A-M, Bernard P-M, Lafont H \& Lairon D (1993) Effects of pea and soybean fibre on postprandial lipaemia and lipoproteins in healthy adults. European Journal of Clinical Nutrition 47, 508-520.

Duprat F, Gallant D, Guilbot A, Mercier C \& Robin JP (1980) L'amidon (Starch). In Les Polymères Végétaux (Vegetable Polymers), pp. 176-231 [B Monties, editor]. Paris: GauthierVillars.

Eskin NAM, Johnson S, Vaisey-Genser M \& McDonald BE (1980) A study of oligosaccharides in a select group of legumes. Journal de l'Institut Canadien de Sciences et Technologies Alimentaires 13, 40-43.

Fischer M, Adkins W, Hall L, Scaman P, Hsi S \& Marlett J (1985) The effects of dietary fibre in a liquid diet on bowel function of mentally retarded individuals. Journal of Mental Deficiency Research 29, 373-381.

Fleming SE (1981) A study of relationships between flatus potential and carbohydrate distribution in legume seeds. Journal of Food Science 46, 794-802.

Focant M, Van Hoecke A, Meurens M \& Vanbelle M (1990) Physiological effects of pea dietary fibre in the rat. In Dietary fibre: Chemical and Biological Aspects, pp. 259-263 [DAT Southgate, K Waldron, IT Johnson and GR Fenwick, editors]. Cambridge: Royal Society of Chemistry.

Frias J, Doblado R \& Vidal-Valverde C (2001) Action of endo/ exo $\alpha$-galactosidases in the $\alpha$-galactoside content of legume seeds. In Proceedings of the 4th European Conference on Grain Legumes, Cracow, Poland, 8-12 July, pp. 140-141 [AEP, editors]. Paris: AEP Editions.

Friedman G (1991) Diet and the irritable bowel syndrome. Gastroenterology Clinics of North America 20, 313-324.

Fukushima M, Ohashi T, Kojima M, Ohba K, Shimizu H, Sonoyama K \& Nakano M (2001) Low density lipoprotein receptor mRNA in rat liver is affected by resistant starch of beans. Lipids 36, 129-134.

Funke U \& Lindhauer MG (1994) Eigenschaften von Giessfilmen aus nativen und chemisch modifizierten Stärken (Properties of casting films from native and chemically modified starches). Starch 46, 384-388.

Gallant DJ, Bouchet B, Buléon A \& Pérez S (1992) Physical characteristics of starch granules and susceptibility to enzymatic degradation. European Journal of Clinical Nutrition 46, Suppl. 2, S3-S16.

Ganiats TG, Norcross WA, Halverson AL, Burford PA \& Palinkas LA (1994) Does Beano prevent gas? A double-blind crossover study of oral alpha-galactosidase to treat dietary oligosaccharide intolerance. Journal of Family Practice 39, $441-445$.

Granfeldt Y, Björck I, Drews A \& Tovar J (1992) An in vitro procedure based on chewing to predict metabolic response to starch in cereal and legume products. European Journal of Clinical Nutrition 46, 649-660.

Grizard D \& Barthomeuf C (1999) Non-digestible oligosaccharides used as prebiotic agents: mode of production and beneficial effects on animal and human health. Reproduction Nutrition Development 39, 563-588.

Guédon C, Ducrotté P, Antoine J-M, Denis P, Colin R \& Lerebours E (1996) Does chronic supplementation of the diet with dietary fibre extracted from pea or carrot affect colonic motility in man? British Journal of Nutrition 76, 51-61.

Gueguen J (1983) Legume seed protein extraction, processing and end product characteristics. Qualitas Plantarum Plant Food and Human Nutrition 32, 267-303.

Gueguen J, Quemener B \& Valdebouze P (1980) Elimination des facteurs antinutritionnels de la féverole Vicia faba L., et du pois Pisum sativum L. au cours de la préparation des isolats protéiques (Elimination of antinutritional factors of fava bean (Vicia faba L.) and peas (Pisum sativum L.) during the preparation of protein isolates). Lebensmittel Wissenshaft und Technologie 13, 72-77.

Guillon F, Renard MGC, Hospers J, Thibault J, Thibault J-F \& Barry JL (1995) Characterisation of residual fibres from fermentation of pea and apple fibres by human colonic bacteria. Journal of the Science of Food and Agriculture 64, 493-499.

Hall RG Jr, Thompson H \& Stother A (1981) Effects of orally administered activated charcoal on intestinal gas. American Journal of Gastroenterology 75, 192-196. 
Hamberg O, Rumessen JJ \& Gudmand-Høyer E (1989) Blood glucose response to pea fiber: comparison with sugar beet fiber and wheat bran. American Journal of Clinical Nutrition 50, 324-328.

Hardinge MG, Swarner JB \& Crooks H (1965) Carbohydrates in foods. Journal of the American Dietetic Association 46, 197-204.

Heymsfield SB, Roongspisuthipong C, Evert M, Casper K, Heller P \& Akrabawi SS (1988) Fiber supplementation of enteral formulas: effects on the bioavailability of major nutrients and gastro-intestinal tolerance. Journal of Parenteral and Enteral Nutrition 12, 265-273.

Hildebrandt LA \& Marlett JA (1991) Starch bioavailability in the upper gastrointestinal tract of colectomized rats. Journal of Nutrition 121, 679-686.

Ibrahim SS, Habiba RA, Shatta AA \& Embaby HE (2002) Effect of soaking, germination, cooking and fermentation on antinutritional factors in cowpeas. Nahrung 46, 92-95.

Iyer V, Salunkhe DK, Sathe SK \& Rockland LB (1980) Quickcooking beans (Phaseolus vulgaris L.). II. Phytates, oligosaccharides and antienzymes. Qualitas Plantarum Plant Food and Human Nutrition 30-45.

Jones RGM, Jones DA \& Hedley C (1998) Partitioning of carbon into starch and soluble carbohydrates during the development and maturation of pea seeds. In Proceedings of the 3rd European Conference on Grain Legumes, Valladolid, Spain, 1419 November, pp. 76-77 [AEP, editors]. Paris: AEP Editions.

Kabir M, Guerre-Millo M, Laromiguière M, Slama G \& Rizkalla SW (2000) Negative regulation of leptin by chronic highglycemic index starch diet. Metabolism 49, 764-769.

Kabir M, Rizkalla SW, Quignard-Boulange A, Guerre-Millo M, Boillot J, Ardouin B, Luo J \& Slama G (1998) A high glycemic index starch diet affects lipid storage-related enzymes in normal and to a lesser extent in diabetic rats. Journal of Nutrition 128, 1878-1883.

Kadlec P, Skulinova M, Kaasova J, Bubnik Z, Pour V \& Dostalova J (2001) Influence of microwave treatment on the soluble carbohydrates of germinated pea. In Proceedings of the 4th European Conference on Grain Legumes, Cracow, Poland, 8-12 July, pp. 420-421. Paris: AEP Editions.

Key F \& Mathers JC (1993) Complex carbohydrate digestion and large bowel fermentation in rats given wholemeal bread and cooked haricot beans (Phaseolus vulgaris) fed in mixed diets. British Journal of Nutrition 69, 497-509.

Kovacs J (1996) Composition of dehydrated powedered mung bean sprout and plant fiber for use as dietary supplement in healthcare. US Patent number US5487894, applicant Arcopharma SA $(\mathrm{CH})$.

Kozlowska H, Zdunczyk Z \& Honke J (1998) Legume grains for food and non food uses. In Proceedings of the 3rd European Conference on Grain Legumes, Valladolid, Spain, 14-19 November, pp. 43-47 [AEP, editors]. Paris: AEP Editions.

Krikken J (1999) Process and system for obtaining starch and proteins from the flour of legumes, in particular peas. US patent number: US5972119, Flottweg GMBH (DE).

Lang V, Bornet FR, Vaugelade P, van Ypersele de Strihou M, Luo J, Pacher N, Rossi F, La Droitte P, Duee PH \& Slama G (1999) Euglycemic hyperinsulinemic clamp to assess posthepatic glucose appearance after carbohydrate loading. 2. Evaluation of corn and mung bean starches in healthy men. American Journal of Clinical Nutrition 69, 1183-1188.

Leakey C (1994) Progress in breeding non-flatulent Phaseolus beans. Grain Legumes 5, 18-19.

Leakey C, Hosfield G \& Dubois A (1998) Mantecas, a new class of beans (Phaseolus vulgaris) of enhanced digestibility. In Proceedings of the 3rd European Conference on Grain Legumes, 14-19 November, Valladolid, Spain, pp. 336-337. Paris: AEP Editions.
Lebet V, Arrigoni E \& Amadò R (1998) Measurement of fermentation products and substrate disappearance during incubation of dietary fibre sources with human faecal flora. Lebensmittel Wissenschaft und Technology 31, 473-479.

Levrat M-A, Behr S, Rémésy C \& Demigné C (1991) Effects of soybean fiber on cecal digestion in rats previously adapted to a fiber-free diet. Journal of Nutrition 121, 672-678.

Lewandowicz G, Błaszczak W, Fornal J \& Voelkel E (2001) Ionic pea starch derivatives for non-food application. In Proceedings of the 4th European Conference on Grain Legumes, Cracow, Poland, 8-12 July, pp. 390-391 [AEP, editor]. Paris: AEP Editions.

Lin Santa HC, Singer D \& Wong TM (1996) Modified soy fiber material of improved sensory properties, US patent number: US5508172, Ralston Purina Co. (US).

Lo GS (1989) Nutritional and physical properties of dietary fiber from soybeans. Cereal Food World 34, 530-534.

Lo GS \& Cole TG (1990) Soy cotyledon fibre products reduce plasma lipids. Atherosclerosis 82, 59-67.

Lo GS, Godberg AP, Lim A, Grundhauser JJ, Anderson C \& Shonfeld G (1986) Soy fiber improves lipid and carbohydrate metabolism in primary hyperlipidemic subjects. Atherosclerosis 62, 239-247.

Madar Z, Arieli B, Trostler N \& Norynberg C (1988) Effect of consuming soybean dietary fiber on fasting and postprandial glucose and insulin level in type II diabetes. Journal of Clinical Biochemistry and Nutrition 4, 165-173.

Madar Z, Reyzik O \& Trostler N (1985) Reduction of glucose and insulin levels in ob/ob obese mice fed soybean dietary fiber. Nutrition Research 5, 305-315.

Mahalko JR, Sandstead HH, Johnson LK, Inmann LF, Milne DB, Warner BRC \& Haring EA (1984) Effects of consuming fiber from corn bran, soy hulls, or apple powder on glucose tolerance and plasma lipids in type II diabetes. American Journal of Clinical Nutrition 39, 25-34.

Martin LJM, Dumon HJW, Lecannu G \& Champ MMJ (2000) Potato and high-amylose maize starches are not equivalent producers of butyrate for the colonic mucosa. British Journal of Nutrition 84, 689-696.

Matheson NK \& Saini HS (1977) Polysaccharide and oligosaccharide changes in germinating lupin cotyledons. Phytochemistry 6, 59-66.

Meares C, Bogracheva T \& Hedley C (2001) Chick pea starch: a new material for the food industry. In Proceedings of the 4th European Conference on Grain Legumes, Cracow, Poland, 8-12 July, pp. 106-107 [AEP, editor]. Paris: AEP Editions.

Munoz JM, Sandstead HH, Jacob RA, Logan GM, Reck SJ, Klevay LM, Dintzis FR, Inglett GE \& Shirey WC (1979) Effects of some cereal brans and textured vegetable protein on plasma lipids. American Journal of Clinical Nutrition 32, 580-592.

Nickel G (1998) Process for preparing products from legumes using centrifugation. US patent number: USA4766204, applicant Woodstone Food Ltd (CA).

Noah L, Guillon F, Bouchet B, Buléon A, Molis C, Gratas M \& Champ M (1998) Digestion of carbohydrate from white beans (Phaseolus vulgaris L.) in healthy humans. Journal of Nutrition 128, 977-985.

Oboh HA, Muzquiz M, Burbano C, Cuadrado C, Pedrosa MM, Ayet G \& Osagie AU (1998) Anti-nutritional constituents of six underutilized legumes grown in Nigeria. Journal of Chromatography 9, 307-312.

Olson AC, Gray GM, Gumbmann MR \& Wagner JR (1982) Nutrient composition of and digestive response to whole and extracted dry beans. Journal of Agriculture and Food Chemistry 30, 26-32.

Petterson DS (1998) Composition and food uses of lupin. In 
Lupins as Crop Plant: Biology, Production and Utilization, pp. 353-384 [JS Gladstone, CA Atkins and J Hamblin, editors]. Wallingford: CAB International.

Pfoertner HN \& Fischer J (2001) Dietary fibres of lupins and other grain legumes. In Advanced Dietary Fibre Technology, pp. 361-366 [BV McCleary and L Prosky, editors]. Oxford: Blackwell Science Ltd.

Potter T, Ellis C \& Levitt M (1985) Activated charcoal: in vivo and in vitro studies of effect on gas formation. Gastroenterology 88, 620-624.

Price KP, Lewis J, Wyatt GM \& Fenwick GR (1988) Flatulence Causes, relation to diet and remedies. Nahrung 32, 609-623.

Quemener B \& Brillouet JM (1983) Ciceritol, a pinitol digalactoside from seeds of chickpea, lentil and white lupin. Phytochemistry 8, 1745-1751.

Rackis JJ (1975) Oligosaccharides of food legumes: alpha-galactosidase activity and flatus problems. In Physiological Effects of Food Carbohydrates, pp. 207-222 [J Allen and J Heilge, editors]. Washington, DC: American Chemical Society.

Reddy BS (1999) Possible mechanisms by which pro- and prebiotics influence colon carcinogenesis and tumour growth Journal of Nutrition 129, 1478S-1482S.

Reddy NR, Pierson MD, Sathe SK \& Salunkhe DK (1984) Chemical, nutritional and physiological aspects of dry bean carbohydrates. Food Chemistry 13, 25-69.

Roberfroid MB (1997) Health benefits of non-digestible oligosaccharides. Advances in Experimental Medicine and Biology 427, 211-219.

Roberfroid MB (1998) Prebiotics and symbiotics: concepts and nutritional properties. British Journal of Nutrition 80, Suppl., S197-S202.

Sahasrabudhe MR, Quinn JR, Patron D, Youngs CG \& Skura BJ (1981) Chemical composition of white bean (Phaseolus vulgaris L.) and functional characteristics of its air-classified protein and starch fractions. Journal of Food Science 46, 1079-1081.

Sandström B, Hansen L \& Sørensen A (1994) Pea lowers fasting and postprandial blood triglyceride concentration in humans. Journal of Nutrition 124, 2386-2396.

Sathe SK, Deshpande SS \& Salunkhe DK (1984) Dry beans of Phaseolus. Chemical composition: carbohydrates, fiber, minerals, vitamins, and lipids. CRC Critical Reviews in Food Science and Nutrition 21, 41-93.

Savage GP \& Deo S (1989) The nutritional value of peas (Pisum sativum). A literature review. Nutrition Abstracts and Reviews (Series A) 59, 66-83.

Schoch TJ \& Maywald EC (1968) Preparation and properties of various legume starches. Cereal Chemistry 45, 564-571.

Schweizer TF, Berkhechi AR, Koellreutter B, Reiman S, Pometta D \& Bron BA (1983) Metabolic effects of dietary fiber from dehulled soybeans in human. American Journal of Clinical Nutrition 38, 1-11.

Seewi G, Gnauck G, Stute R \& Chantelau E (1999) Effects on parameters of glucose homeostasis in healthy humans from ingestion of leguminous versus maize starches. European Journal of Nutrition 38, 183-189.

Shorey RL, Day PJ, Willis RA, Lo GS \& Steinke FH (1985) Effects of soybean polysaccharide on plama lipids. Journal of the American Dietetic Association 85, 1461-1465.

Skrabanja V, Liljeberg HG, Hedley CL, Kreft I \& Bjorck IM (1999) Influence of genotype and processing on the in vitro rate of starch hydrolysis and resistant starch formation in peas (Pisum sativum L.). Journal of Agricultural and Food Chemistry 47, 2033-2039.

Slavin JL, Nelson NA, McNamara EA \& Cashmere K (1985) Bowel function of healthy men consuming liquid diets with and without dietary fiber. Journal of Parenteral and Enteral Nutrition 9, 317-321.
Soral-Śmietana M, Lewandowicz G \& Wronkowska M (2001a) Pea starch: the material for resistant starch (RS3). In Proceedings of the 4th European Conference on Grain Legumes, Cracow, Poland, 8-12 July, pp. 104-105 [AEP, editors]. Paris: AEP Editions.

Soral-Śmietana M, Wronkowska M, Lewandowicz G \& Świgoń A $(2001 b)$ Damage of pea starch granules vs structure and functional properties. In Proceedings of the 4th European Conference on Grain Legumes, Cracow, Poland, 8-12 July, pp. 388-389 [AEP, editor]. Paris: AEP Editions.

Sosulski F (1979) Yield and functional properties of air-classified protein and starch fractions from eight legume flours. Journal of the American Oil Chemistry Society 56, 292-295.

Sosulski FW \& McCurdy AR (1987) Functionality of flours, protein fractions and isolates from field peas and faba bean. Journal of Food Science 47, 498-502.

Sosulski R, Hoover R, Tyler RT, Saskatoon Murray ED \& Winnipeg BDA (1985) Differential scanning calorimetry of air classified starch and protein fractions from eight legume species. Starch/Stärke 37, 257-262.

Szukala J, Gulewicz P \& Gulewicz K (2001) Evaluation of influence of agricultural factors on $\alpha$-galactosides biosynthesis in faba bean seeds. In Proceedings of the 4th European Conference on Grain Legumes, Cracow, Poland, 8-12 July, pp. 368-369 [AEP, editors]. Paris: AEP Editions.

Taper LJ, Milam RS, McCallister MS, Bowen PE \& Thye FW (1988) Mineral retention in young men consuming soy-fiberaugmented liquid formula diets. American Journal of Clinical Nutrition 48, 305-311.

Tayler RT, Youngs CG \& Sosulski FW (1981) Air classification of legumes I; Separation efficiency, yield and composition of the starch and protein fractions. Cereal Chemistry 58, 114-148.

Taylor GR \& Williams CM (1998) Effects of probiotics and prebiotics on blood lipids. British Journal of Nutrition $\mathbf{8 0}$, S225-S230

Titgemeyer EC, Bourquin LD, Fahey GC \& Garleb KA (1991) Fermentability of various fiber sources by human, fecal bacteria in vitro. American Journal of Clinical Nutrition 53, 1418-1424.

Tovar J (1996) Bioavailability of carbohydrates in legumes: digestible and indigestible fractions. Archivos Latinoamericanos de Nutricion 44, Suppl. 1, 36S-40S.

Tsai AC, Mott EL, Owen GM, Bennick MR, Lo GS \& Steinke FH (1983) Effects of soy polysaccharide on gastrointestinal functions, nutrient balance, steroids excretion, glucose tolerance, serum lipids and other parameters in humans. American Journal Clinical Nutrition 38, 504-511.

Tsai AC, Vinik AI, Lasichak A \& Lo GS (1987) Effects of soy polysaccharide on postprandial plasma glucose, insulin, glucagon, pancreatic polypeptide, somastostatin, and triglycerides in obese diabetic patients. American Journal of Clinical Nutrition 45, 596-601.

Uberoi SK, Vadhera S \& Soni GL (1992) Role of dietary fibre from pulses and cereals as hypocholesterolemic and hypolipidemic agent. Journal of Food Science and Technology 29, $281-283$.

Vanderhoof JA, Murray ND, Paule CL \& Ostrom KM (1997) Uses of soy fiber in acute diarrhea in infants and toddlers. Clinical Pediatrics March, 135-139.

Van der Meulen J, Bakker JG, Smits B \& de Visser H (1997) Effects of source of starch on net portal flux of glucose, lactate, volatile fatty acids and amino acids in the pig. British Journal of Nutrition 78, 533-544.

Van Laar H, Tamminga S, Williams BA \& Verstegen MWA (2000) Fermentation of the endopserm cell walls of monocotyledon and dicotyledon plant species by faecal microbes from pigs. The relationships between cell wall characteristics and fermentability. Animal Feed Science and Technology 88, 13-30. 
Van Laar H, Tamminga S, Williams BA, Verstegen MWA \& Engels M (1999) Fermentation characteristics of cell-wall sugars from soya bean meal, and from separated endopserm and hulls of soya beans. Animal Feed Science and Technology 79, 179-193.

Van Loo J, Cummings J, Delzenne N, Englyst H, Franck A, Hopkins M, Kok N, Macfarlane G, Newton D, Quigley M, Roberfroid M, van Vliet T \& van den Heuvel E (1999) Functional food properties of non-digestible oligosaccharides: a consensus report from the ENDO project (DGXII AIRIICT94-1095). British Journal of Nutrition 81, 121-132.
Vidal-Valverde C, Frias J, Lambein F \& Kuo Y-H (2001) Increasing the functionality of legumes by germination. In Proceedings of the 4th European Conference on Grain Legumes, Cracow, Poland, 8-12 July, pp. 422-423 [AEP, editors]. Paris: AEP Editions.

Weightman RM, Renard CMGC \& Thibault JF (1994) Structure and properties of the polysaccharides from pea hulls. I: Chemical extraction and fractionation of the polysaccharides. Carbohydrate Polymers 24, 139-148. 